\title{
Testing Nonprofit State Culture: Its Impact on the Health of the Nonprofit Sector
}

\author{
${ }^{1}$ Political Science and Public Administration, University of North Carolina at Charlotte, 9201 University City Blvd, Charlotte, NC, \\ USA, E-mail:spettijo@uncc.edu \\ ${ }^{2}$ Center on Nonprofits and Philanthropyy, Urban Institute, , 2100 M Street, NW, Washington, D.C., District of Columbia, USA
}

\begin{abstract}
:
Government monitors, regulates, and funds nonprofit organizations, making it is a key player in the health of the nonprofit sector in the United States. However, not all states treat nonprofits similarly. Prior work identified three types of state nonprofit culture (Pettijohn, S. L., and E. T. Boris. 2017. State Nonprofit Culture: Assessing the Impact of State Regulation on the Government-Nonprofit Relationship. Grand Rapids, MI: ARNOVA Presentation.), or a unique set of attitudes and beliefs that shape the operating norms between state government and nonprofits. This article analyzes whether differences among state nonprofit culture are measureable in the government-nonprofit relationship. Using data from the Urban Institute's 2013 Nonprofit-Government Contracting and Grants survey, we find there are significant differences in the government-nonprofit funding relationships, which means nonprofits operating in certain state nonprofit cultures face different types and degrees of risk to their organization's overall health.
\end{abstract}

Keywords: nonprofit government relations, state government, nonprofit regulation

DOI: $10.1515 / \mathrm{npf}-2018-0012$

Government is a key player in the health of the nonprofit sector in the United States. Not only do local, state, and federal governments account for more than one-third of the sector's total revenue (McKeever, Dietz, and Fyffe 2016), they also regulate and monitor nonprofit activity, all of which profoundly impacts the health of the nonprofit sector. The relationship between nonprofits and state government has become more important as resource constraints at the Internal Revenue Service (IRS) have weakened federal oversight of charitable organizations (Mayer 2016), further strengthening the state's role in regulating nonprofits. Lott and Fremont-Smith find, "State governments have a direct impact on nonprofit charities in several ways: they regulate them, they exempt them from major taxes, and they use them as vehicles to deliver publicly funded services" $(2017,163)$. However, each state determines how it regulates, exempts, and partners with nonprofits operating within its boundaries. This means a nonprofit operating in one state may have more complex requirements, enjoy greater support or face more opposition from its state government compared to a nonprofit operating in another state. Recent work identified three types of state nonprofit cultures that describe the relationship between government and nonprofits at the state level. In this paper, we explore whether there are significant differences for nonprofits that operate in these three different state nonprofit cultures. Specifically, the paper examines differences between state nonprofit culture and the level of financial risk (assumed in different types of contracts with government agencies) or differences in problems nonprofits report on securing, managing, and reporting on government funds. We begin by discussing the three types of state nonprofit cultures and the governmentnonprofit funding relationship. Then, we outline data sources, variables considered, and methods used. The final two sections present the results and findings.

\section{State Nonprofit Culture}

Political scientists have long discussed the importance of how U.S. states were settled and the role ethnic and religious values played in a state's political culture, or its "system of shared values that legitimate a preferred set of social relationships" (Lieske 2012, 110-111). A state's political culture shapes social and political preferences by helping individuals understand who they are, how they should behave, and whether an institution is legitimate (Lieske 2012; Wildavsky 1987). Recent research expands upon state political culture by integrating a state's political and philanthropic culture with the state's nonprofit regulatory regime to help explain the state's nonprofit culture, or the behaviors, values, and norms that define how government and nonprofits interact (Pettijohn and Boris (2017). 
To determine a state's nonprofit culture, Pettijohn and Boris (2017) use Lieske's (2010) model of social and political culture within states, which considers race and ethnic ancestry, religious preferences, and social structures, ${ }^{1}$ and include variables to measure the political ideology of the state, ${ }^{2}$ state-level regulation of its nonprofit sector, ${ }^{3}$ the state government's fiscal environment, ${ }^{4}$ and the size of the nonprofit sector. ${ }^{5}$ The analysis identified three distinct state nonprofit cultures in the U.S, which can be discussed by adapting Young's (2000) work on understanding the government-nonprofit relationship. Pettijohn and Boris (2017) found that within a state, nonprofits operate in ways that complement, supplement, or behave independently from state government.

Nonprofits operating in a complementary state nonprofit culture appear to work with government to provide services. While this is the culture of the fewest number of states, these states have a significant nonprofit presence in terms of revenues and assets. State governments in this group, spend significantly more on education, welfare, and public safety compared to states in the other two culture groups, rely on the federal government for smaller portions of their state budgets, and require individuals to pay a higher percentage of their income in state taxes. These states also tend to elect more Democrats and are more regulated than states in the other two culture groups.

The second state nonprofit culture is one where government and nonprofits appear to supplement each other, or as Young articulates, "nonprofits are seen as fulfilling a demand for public goods left unsatisfied by government" (1999, 33). Here, Pettijohn and Boris (2017) find the supplemental state nonprofit culture consists of states that are relatively healthy, fiscally speaking, with government spending on education, welfare, and public safety no different from the other two state nonprofit culture groups. However, states with the supplemental state nonprofit culture have significantly more nonprofits per capita than states with an individual state nonprofit culture. Since the number of nonprofits per resident is larger than in other states, individuals have more options to exercise choices for association and services that reflect their individual values.

In the final state nonprofit culture, nonprofits appear to operate independent of government. It is on the opposite end of the spectrum from the complementary state nonprofit culture. These states have the fewest nonprofits and nonprofit dollars per resident even though nonprofits operate with fewer regulations compared to those in both the complementary and supplementary culture states. Independent nonprofit culture states tend to receive a larger percentage of their state budgets from the federal government, but they spend less on education and welfare, while having the healthiest fiscal conditions. These states have individuals contributing larger amounts of funding to nonprofits (based on average itemized contributions), which may indicate the relationship is between individuals and nonprofits with minimum government involvement. Finally, the model reveals a higher percentage of individuals voted for Trump and more Republicans holding statewide elected offices. Table 1 lists the three state nonprofit cultures and the states that belong to each.

Table 1: State nonprofit culture.

\begin{tabular}{|c|c|c|}
\hline Complementary & Supplementary & Independent \\
\hline Connecticut & Alaska & Alabama \\
\hline Illinois & California & Arizona \\
\hline Maryland & Colorado & Arkansas \\
\hline Massachusetts & Delaware & Florida \\
\hline Michigan & Georgia & Idaho \\
\hline Minnesota & Hawaii & Kansas \\
\hline Nebraska & Indiana & Kentucky \\
\hline New Hampshire & Iowa & Louisiana \\
\hline New York & Maine & Mississippi \\
\hline North Dakota & Missouri & Nevada \\
\hline Pennsylvania & Montana & New Mexico \\
\hline Rhode Island & New Jersey & Oklahoma \\
\hline \multirow[t]{7}{*}{ Washington } & North Carolina & Oregon \\
\hline & Ohio & South Carolina \\
\hline & South Dakota & Tennessee \\
\hline & Vermont & Texas \\
\hline & Virginia & Utah \\
\hline & Wisconsin & West Virginia \\
\hline & & Wyoming \\
\hline
\end{tabular}




\section{Government Funding of Nonprofit Organizations}

Government funding accounts for nearly one-third of the total nonprofit sector's revenue (McKeever, Dietz, and Fyffe 2016), but it often comes with requirements that force or strongly encourage nonprofits to alter their behavior and operations. These demands may affect the health of nonprofit organizations receiving government funding. Prior research has extensively studied the impact government funding has on nonprofits in the following areas: governance (Guo 2007; Peterson 1970; Piven and Cloward 1971; Smith and Lipsky 1993), volunteers (Nowland-Foreman 2002; Ebaugh, Chaftez, and Pipes 2005; Smith and Lipsky 1993; Van Til 1988), mission (Rangan 2004; Pettijohn and Boris 2013), political activity (e. g. Chaves, Stephens, and Galaskiewicz 2004), advocacy (e. g. Mosley 2012; Neumayr, Schneider, and Meyer 2015; Salamon 1987), loss of autonomy (Grojnberg 1993), administrative efficiency (Frumkin and Kim 2002; Grojnberg 1993), and strategic decision-making (Verschuere and De Corte 2014). This paper, however, approaches the government-nonprofit relationship from a different perspective. Instead of focusing on the impact government funding has on nonprofits, it focuses on whether there are measurable differences in the government-nonprofit relationship among the three types of state nonprofit culture. Specifically, the paper examines the relationship related to the level of financial risk (assumed in different types of contracts with government agencies) or differences in problems nonprofits report on securing, managing, and reporting on government funds, which may impact the health of the nonprofit sector.

\subsection{Implementation of Formal Government-Nonprofit Funding Relationships}

First, we examine the formal government-nonprofit funding relationship by assessing the types of contracts used to execute the terms and conditions of government funding for nonprofits in different state-nonprofit cultures. Contract type determines who accepts the financial risk should actual costs of the goods/services procured exceed the expected costs. The Federal Acquisition Regulation Systems (FAR) discusses two broad contract types: firm-fixed price and cost-reimbursement and notes that firm-fixed price contracts are governments preferred contract type (48 C. F. R.). FAR requires federal agencies to use firm-fixed-price contracts "in which the contractor [nonprofit] has full responsibility for the performance costs and resulting profit (or loss)" (48 C. F. R. § 16.101b). Firm-fixed price contracts require the least amount of interaction between the government and its contractor because the terms and conditions of the contract are set in advance, require significantly less oversight than other contract types, and protect the government from paying additional costs (48 C. F. R. $\S 16$; U.S. Government Accountability Office (GAO) 2009). This allows government to shift the financial risk of the contracted work to the nonprofit, which then bears the financial burden should unexpected or higher than expected costs arise. While a longer-term relationship may mitigate some of the risk of a firm-fixed price contract, broader issues regarding supply and demand and inflation in the general economy still pose a financial risk to nonprofit organizations operating under firm-fixed price contracts. Since nonprofits operating in the supplemental state nonprofit culture are providing services when government is unwilling or unable to do so, we hypothesize:

$\mathrm{H}_{1}$ : Nonprofits operating in supplementary culture state are more likely to report firm-fixed price contracts, with government shifting the financial risk to the nonprofit.

Cost-reimbursement contracts are in direct contrast to firm-fixed price contracts. FAR only permits the use of this type of contract when the agency has determined a firm-fixed price contract is inadequate for the goods or services in question (48 C. F. R. § 16.3). Agencies are advised that cost-reimbursement contracts are "considered high risk for the government because of the potential for cost escalation and because the government pays a contractor's costs of performance regardless of whether the work is completed" (U.S. Government Accountability Office (GAO) 2009, p. 1). It also costs the government more to use cost reimbursement contracts because these contracts require more monitoring and oversight (U.S. Government Accountability Office (GAO) 2009) because government assumes the financial risk should the cost of services exceed the contracted amount. When government and nonprofits operate independently of each other, we expect nonprofits may not be willing to accept the financial risk of providing government services, and thus, we hypothesize:

$\mathrm{H}_{2}$ : Nonprofits operating in independent culture states are more likely to report cost reimbursement contracts, which means government retains the financial risk.

The government can also use various incentive contracts with both firm-fixed price and cost reimbursable contracts to motivate the contractor to perform tasks that are hard to define and specify, and/or when government wants to discourage contractor inefficiency or waste (48 C. F. R. § 16.4). These performance-based contracts 
spilt the risk more evenly between the government and nonprofit and often require more interaction between government and nonprofit officials to negotiate and agree on performance targets. Thus, nonprofits partnering with government to provide services in these types of contracts may be more likely to share the financial risk more equally, so we hypothesize:

$\mathrm{H}_{3}$ : Nonprofits operating in complementary culture states are more likely to report performance-based price contracts.

Finally, some contracts require nonprofits to cost share or match a portion of the costs incurred by the government for the services. Cost sharing or matching requirements impose financial burdens on nonprofits as they "potentially limit the sector's ability to effectively partner with the federal government, can lead to nonprofits providing fewer or lower-quality federal services, and, over the long term, could risk the viability of the sector" (U.S. Government Accountability Office (GAO) 2010, p. 22). Nonprofits with these requirements must dedicate existing resources or incur fundraising costs to match government support, but, in a complementary culture, there is likely to be an alignment of goals between the nonprofits and government partners leading to a willingness of the nonprofit to raise the additional resources that enable it to provide the services. As a result, we hypothesize:

$\mathrm{H}_{4}$ : Nonprofits operating in complementary culture states are more likely to report sharing or matching requirements.

\subsection{Problems and Feedback: the Nonprofit Perspective}

While government funding of nonprofits continues to increase, the relationship is not without problems, and the problems nonprofits report threaten the health of the nonprofit sector. Nonprofits often face obstacles at many points in securing, managing, and reporting on government funds. Following the great recession of 2008, a national random survey of human service nonprofit organizations revealed the scope of problems that nonprofits endured (Boris et al. 2010). Many nonprofit leaders reported that government failed to reimburse their organizations within the allotted time frame outlined in the contract, made changes to the contract or grant after it was executed, and failed to cover the full cost of services provided (Boris et al. 2010; Pettijohn and Boris 2013). These problems forced nonprofits to take out loans, use existing credit to ensure payrolls were met, and cut employee benefits and hours, in their efforts to provide services and retain employees (Boris et al. 2010).

The problems nonprofits report in their work with government agencies begins before funding is awarded and continue after the contract is completed. Nonprofits report they are burdened by overly complicated application and reporting requirements (Boris et al. 2010; 2013). Inconsistencies in definitions related to allowable and unallowable and direct and indirect costs among local, state, and federal governments further exacerbate the problems nonprofits face and add more layers of complexity and costs of application and compliance in the government funding processes (U.S. Government Accountability Office (GAO) 2010).

Ideally, when such problems arise, government and nonprofits would have open feedback loops that allow both parties to communicate effectively and work together to resolve problems. Nonprofits, however, may be hesitant to notify government officials of their problems and frustrations out of fear of losing their government funding. To speak up, nonprofits may have to feel as though they are equal partners and have a trusting relationship with their government funders. Firm-fixed price contracts provide clearer terms and conditions which leave little room for misinterpretation. Cost reimbursement and performance-based contracts are, by definition, more ambiguous and only used when the requirements are uncertain, which could create more problems and therefore, more opportunity for feedback. Since the relationship between problems in the contracting processes and state nonprofit culture are not evident, we hypothesize:

$\mathrm{H}_{5}$ : Nonprofits working in different nonprofit culture states will experience problems with government funders differently.

$\mathrm{H}_{6}$ : Nonprofits operating in different nonprofit culture states will not provide feedback at the same rates.

\section{Data, Variables, and Methods}

This analysis uses data from the Urban Institute's 2013 Nonprofit-Government Contracting and Grants survey, which asks nonprofit leaders about their relationships with government in 2012. The national, randomly drawn sample of 20,000 nonprofits organization consisted of 80,098 501(c)(3) nonprofit organizations in the Urban 
Institute's National Center for Charitable Statistics (NCCS) database. The sample was limited to those nonprofits required to file an annual financial statement (Form 990) with the U.S. Internal Review Service and reported more than $\$ 100,000$ in expenditures. The study does not include hospitals or higher education institutions as well as nonprofits not likely to have government contracts and grants. To ensure a representative sample, prior to selection, organizations were stratified by state, type of nonprofit, and size of nonprofit. Smaller states were oversampled to ensure adequate sample sizes for state-level analysis.

The final response rate was $33 \%$ with 4,024 organizations responding (see Pettijohn and Boris 2013 for more information). This analysis focuses on the responses from 2,611 nonprofits reporting government funding. ${ }^{6}$ These survey data are merged with core data from NCCS for 2012, which provided financial information about the organizations, and with Pettijohn and Boris (2017) classification of states according to their state nonprofit culture.

Table 2 outlines the dependent and independent variables used in the analysis. To isolate the impact of state culture on government-nonprofit relations, a number of variables are included in the analysis. Here, we control for funder characteristics (level of government the nonprofit receives funding from, number of agencies the nonprofit receives funding from, and number of contracts or grants) and organizational characteristics (size based on organization's expenses and type of nonprofit based on National Taxonomy of Exempt Entities (NTEE) code).

Table 2: Key variable description.

\begin{tabular}{|c|c|c|}
\hline Category & Variable & Description \\
\hline \multirow{12}{*}{$\begin{array}{l}\text { Dependent } \\
\text { variables }\end{array}$} & Contract type & \\
\hline & Firm-fixed & $\begin{array}{l}\text { Binomial indicator; a nonprofit received a firm-fixed price contract }(1= \\
\text { yes; } 0=\text { no) }\end{array}$ \\
\hline & Cost reimbursement & $\begin{array}{l}\text { Binomial indicator; a nonprofit received a cost-reimbursement } \\
\text { contract }(1=\text { yes; } 0=\text { no })\end{array}$ \\
\hline & Performance & $\begin{array}{l}\text { Binomial indicator; a nonprofit received a performance-based contract } \\
(1=\text { yes; } 0=\text { no) }\end{array}$ \\
\hline & Cost sharing & $\begin{array}{l}\text { Binomial indicator; a nonprofit is required to share cost or match } \\
\text { government funding }(1=\text { yes; } 0=\text { no) }\end{array}$ \\
\hline & $\begin{array}{l}\text { Nonprofit experience with } \\
\text { government }\end{array}$ & \\
\hline & Late payment & $\begin{array}{l}\text { Ordinal variable; nonprofit's experience with late payments (beyond } \\
\text { contract specifications) was } 0=\text { not a problem, } 1=\text { small problem, } 2=\text { big } \\
\text { problem }\end{array}$ \\
\hline & Insufficient payments & $\begin{array}{l}\text { Ordinal variable; nonprofit's experience with payments not covering } \\
\text { full cost of contracted services was } 0=\text { not a problem, } 1=\text { small } \\
\text { problem, } 2=\text { big problem }\end{array}$ \\
\hline & Application process & $\begin{array}{l}\text { Ordinal variable; nonprofit's experience with complexity of } / \text { time } \\
\text { required by application process was } 0=\text { not a problem, } 1=\text { small } \\
\text { problem, } 2=\text { big problem }\end{array}$ \\
\hline & Contract changes & $\begin{array}{l}\text { Ordinal variable; nonprofit's experience with government changes to } \\
\text { contract or grant midstream was } 0=\text { not a problem, } 1=\text { small problem, } \\
2=\text { big problem }\end{array}$ \\
\hline & Reporting process & $\begin{array}{l}\text { Ordinal variable; nonprofit's experience with complexity of / time } \\
\text { required for reporting was } 0=\text { not a problem, } 1=\text { small problem, } 2=\text { big } \\
\text { problem }\end{array}$ \\
\hline & Provided feedback & $\begin{array}{l}\text { Binomial indicator; a nonprofit provided feedback to government }(1= \\
\text { yes; } 0=\text { no) }\end{array}$ \\
\hline \multirow{4}{*}{$\begin{array}{l}\text { Independent } \\
\text { variables }\end{array}$} & State nonprofit culture & \\
\hline & Complementary & $\begin{array}{l}\text { Binomial indicator; a nonprofit is located in complementary culture } \\
\text { state }(1=\text { yes; } 0=\text { no })\end{array}$ \\
\hline & Supplementary & $\begin{array}{l}\text { Binomial indicator; a nonprofit is located in supplementary culture } \\
\text { state }(1=\text { yes; } 0=\text { no })\end{array}$ \\
\hline & Independent & $\begin{array}{l}\text { Binomial indicator; a nonprofit is located in independent culture state } \\
(1=\text { yes; } 0=\text { no) }\end{array}$ \\
\hline
\end{tabular}

The non-linear, binary nature of the first four dependent variables indicates a logit model is the most appropriate approach to test the first four hypotheses (Gujarati and Porter 2009). For the remaining two hypotheses, where the dependent variable is non-continuous but ordered, ordered logit is the most appropriate statisti- 
cal test (Gujarati and Porter 2009). The results report odds ratios and robust standard errors. All analyses are weighted to represent the nonprofit sector with government funding within each state (except as noted).

\section{Descriptive Statistics}

We begin by examining the size and scope of the funding relationships between nonprofits and governments. We find, on average, nonprofits in a complementary culture state received more government funding, both in terms of the average number of agreements and dollars, than those in an independent culture state (Table 3). As Salamon (1995) notes, the complementary view often involves government financing services that are delivered by nonprofits. These nonprofits also received grants from more government agencies than other states.

Table 3: Size and scope of government-nonprofit relationship by state nonprofit culture.

\begin{tabular}{llll}
\hline & Complementary & Supplementary & Independent \\
\hline Average number of nonprofits & 37,064 & 34,496 & 24,491 \\
Average nonprofit assets (million) & $\$ 185,354$ & $\$ 103,453$ & $\$ 59,004$ \\
Average number of contracts and grants & 1,591 & 1,168 & 698 \\
Average dollar value of contracts and grants (million) & $\$ 4,471$ & $\$ 2,929$ & $\$ 1,304$ \\
\hline
\end{tabular}

We find that while the fiscal condition of the states with independent cultures are healthier than states with complementary state cultures, the nonprofit sectors in the independent state culture group tend to be weaker. That is, states in the independent state culture group not only had significantly smaller nonprofit sectors per capita, but also nonprofits with government funding were more likely to report a deficit at the end of 2012. Nonprofits operating in independent culture states were also significantly more likely to cut health insurance, retirement, and other staff benefits for their employees, and they were more likely to take out loans or lines of credit than nonprofits in states that complemented or supplemented government services. This suggests an inverse relationship between the fiscal conditions of state government and nonprofits in the state. It also suggests the importance of government funding for the health of nonprofits since higher average contributions did not compensate for lower levels of government funding. Table 4 includes descriptive statistics for the percent of respondents receiving government funding from each level of government by state nonprofit culture.

Table 4: Percent of nonprofits reporting level of government funding by state nonprofit culture.

\begin{tabular}{lllll}
\hline & Complementary & Supplementary & Independent & Total \\
\hline Local only & 2.9 & 3.9 & 2.9 & 9.7 \\
State only & 6.2 & 6.4 & 6.2 & 18.8 \\
Federal only & 3.1 & 3.6 & 4.8 & 11.5 \\
Local and state (no federal) & 5.5 & 5.9 & 4.9 & 16.3 \\
Local and federal (no state) & 1.5 & 2.1 & 1.7 & 5.3 \\
State and federal (no local) & 4.3 & 6.3 & 6.7 & 17.3 \\
Local, state, and federal (all levels) & 7.4 & 7.6 & 6.1 & 21.1 \\
Total & 30.8 & 35.8 & 33.3 & 100.0 \\
\hline
\end{tabular}

${ }^{1}$ Notes: Subtotals may not sum to totals because of rounding.

The results for the size and scope of the government-nonprofit relationship are as one might expect. That is, when we consider the driving factors that determine which state culture a state falls into, we see an overlap of characteristics in state nonprofit culture categories and the size and scope of the government-nonprofit funding relationship. For example, we expect nonprofits in complementary culture states to partner with government to provide services. We also expect nonprofits in supplementary culture states to have less funding, since government is providing services at a level the average citizen desires, which may not fully satisfy some citizens who turn to nonprofits to fill their needs. Finally, nonprofits in independent culture states receive less government funding, which reinforces the finding that in these states nonprofits and government are more independent of each other. 


\section{Analytic Results and Discussion}

While the results for the six hypotheses are mixed, there are measureable differences in the governmentnonprofit funding relationship among state nonprofit cultures (Table 5). Nonprofits operating in the independent culture states were significantly more likely to report a cost reimbursement contract, but they were also more likely to report a cost sharing or matching requirement. As for experiencing problems with government agencies, nonprofits in independent culture states were significantly less likely to report problems securing, managing, and reporting on government funding than their counterparts. These findings are discussed in greater detail below. 


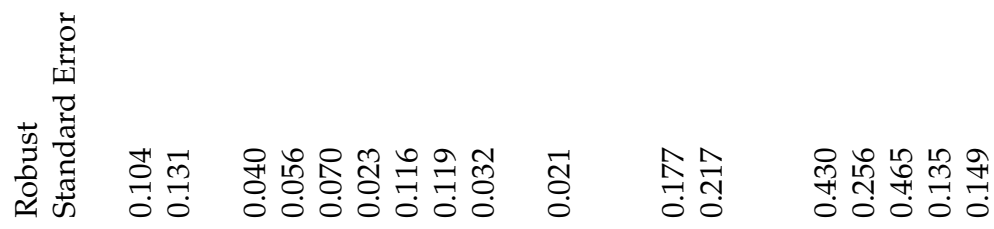

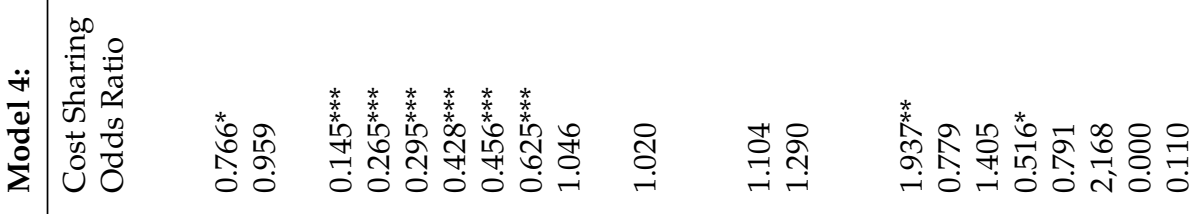

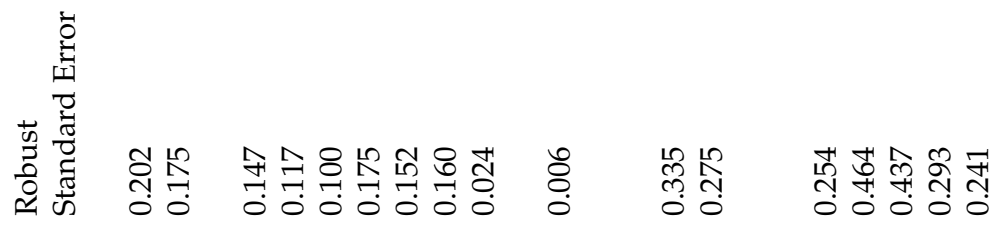

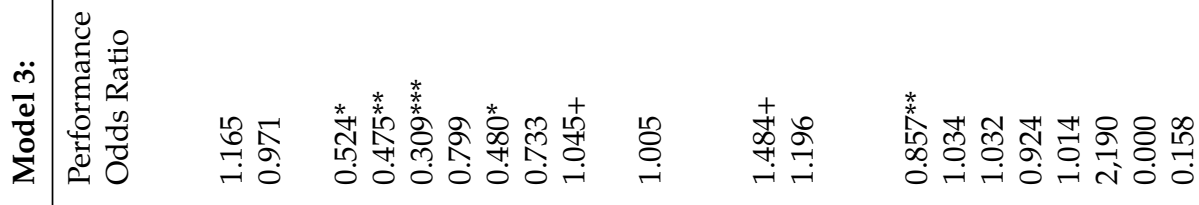

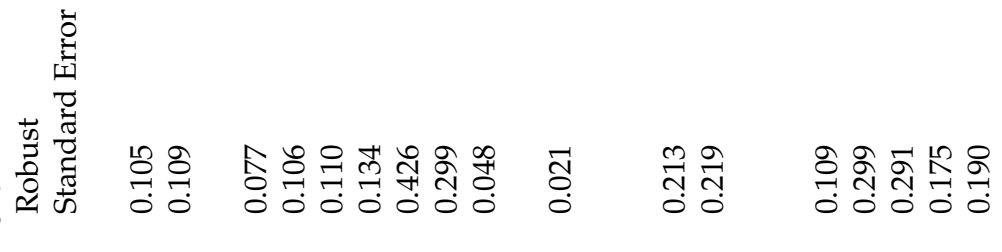

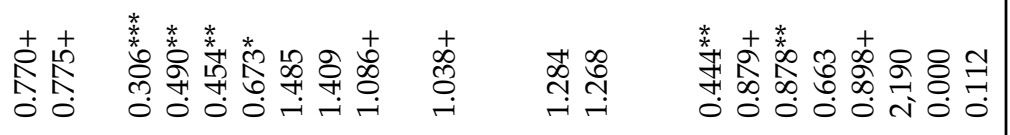

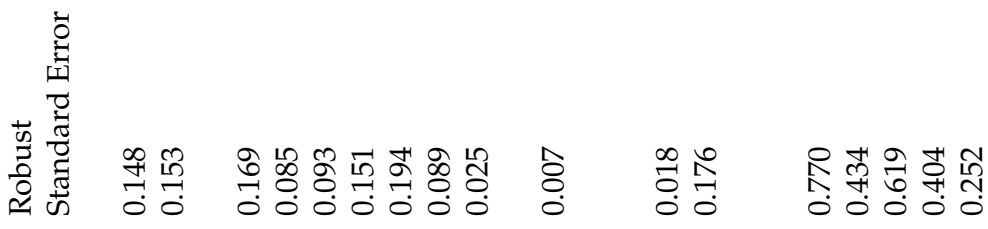$$
\text { 政 }
$$ 


\subsection{Implementation of Formal Government-Nonprofit Funding Relationships}

When examining the types of contracts government uses to award nonprofits funds, only cost reimbursement contracts gained significance in the analysis. Table 5 shows that while the differences among culture moved in the direction expected, the other relationships were not significant, so there is no support for hypotheses one (fixed contracts) and three (performance contracts).

We expected complementary culture states to report more cost sharing or matching requirements, which was partially supported by the analysis. That is, nonprofits in complementary culture states are significantly more likely to report a cost-sharing requirement than their counterparts in independent culture states, but there is no difference in the likelihood of nonprofits in complimentary culture states reporting more cost sharing requirements than nonprofits in supplementary culture states. Yet, overall, the relationships we find between nonprofits and government via contract type align with what we expected for each group. That is, we see in complementary culture states, nonprofits work with government to share the financial risk of the relationship as well as the cost of providing services to clients, and in the independent culture group, contract types require the government to assume the risks for services it seeks nonprofits to deliver. However, nonprofits in supplementary culture states are no more likely to use a firm-fixed price contract.

\subsection{Reported Problems by Nonprofits}

All types and sizes of nonprofits reported some level of difficulty with the five problem areas explored in the survey. However, nonprofits in the supplementary culture states were more likely to report significant problems in three of the five areas (Table 6) compared to respondents in independent culture states. These nonprofits reported late payments for services rendered, awards not covering the full cost of services, and time-consuming application requirements were more problematic than nonprofits operating in the independent culture states. 


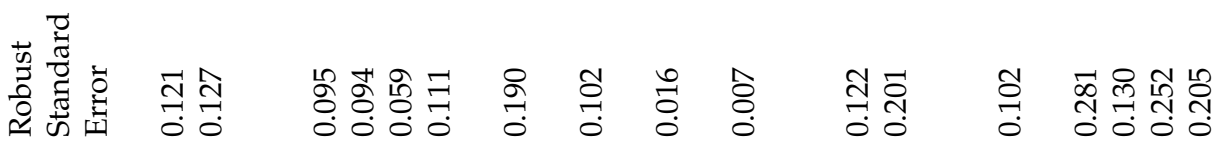

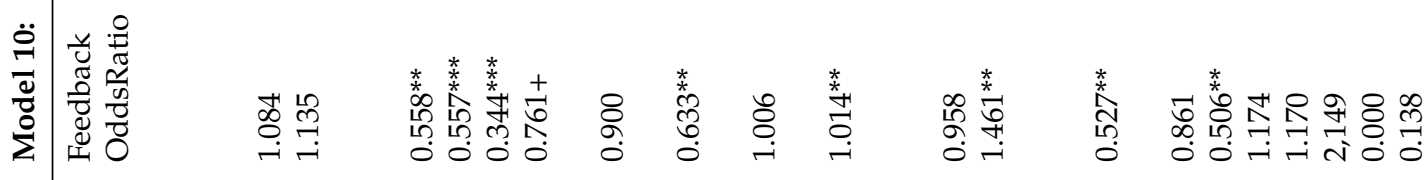

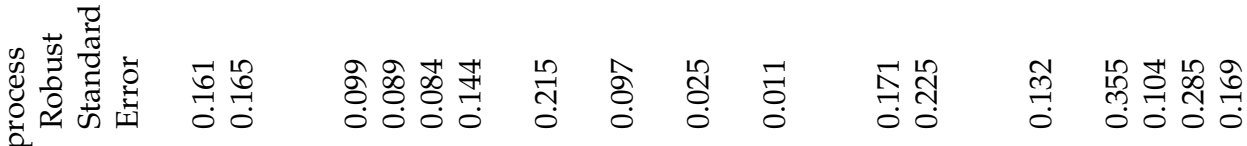

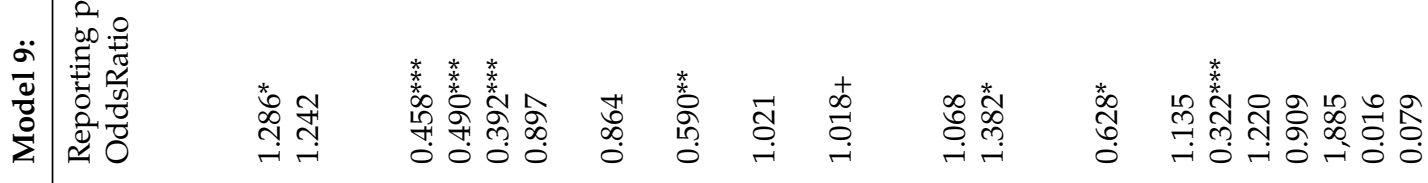

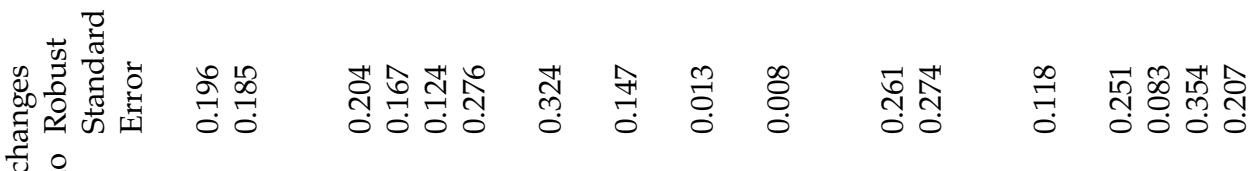

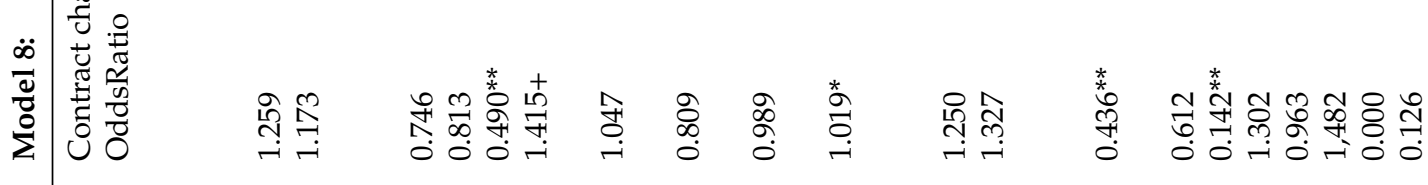

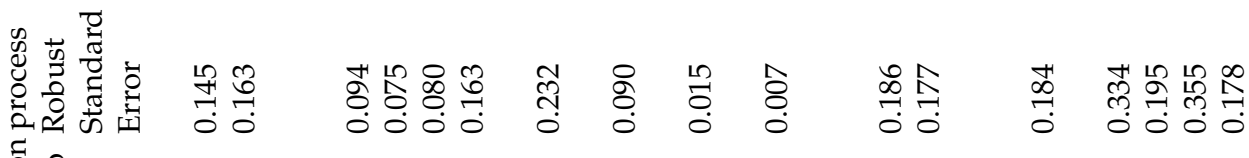

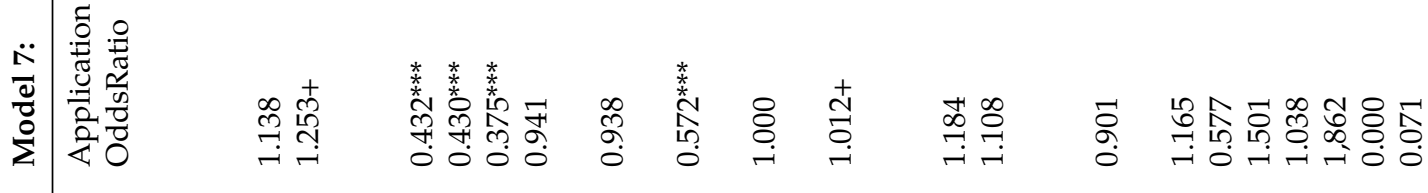
苞若

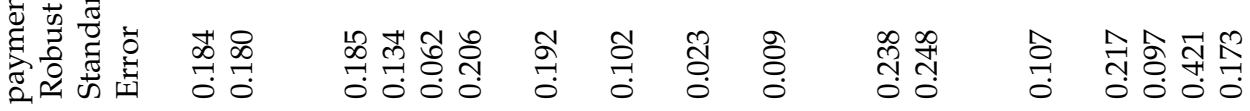
苞

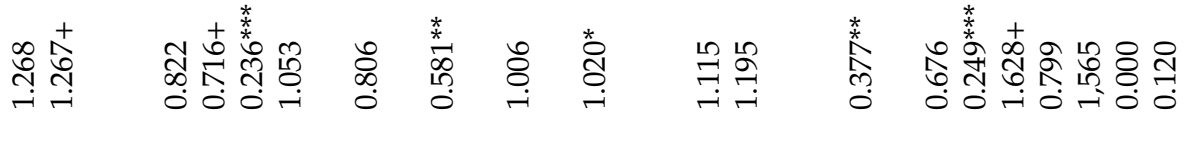

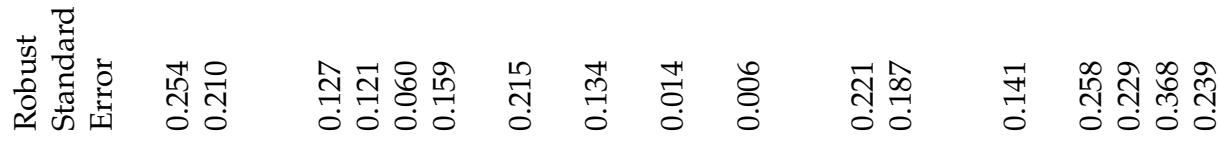

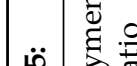

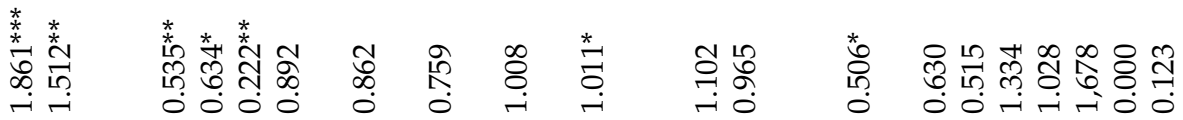

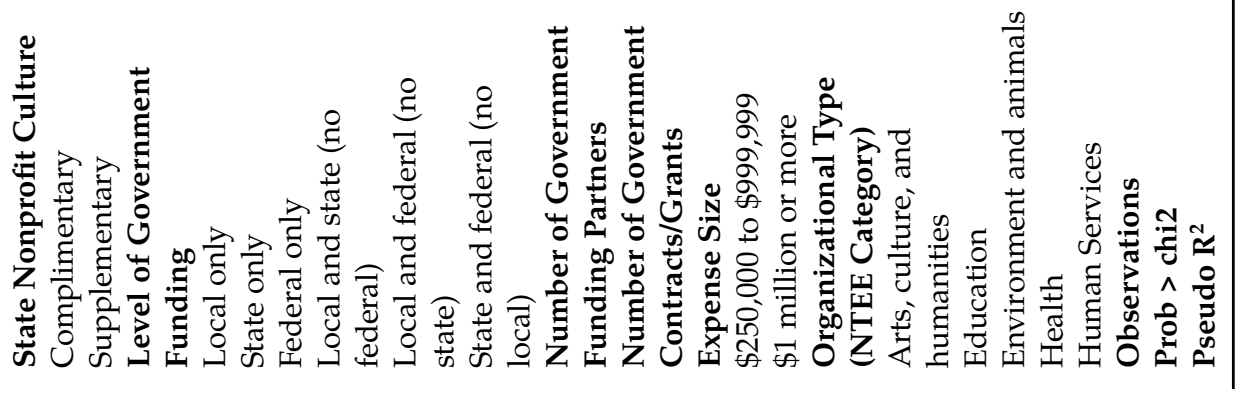


Nonprofits in complementary states reported significant problems related to late payments and complex reporting requirements. Additionally, complementary states were more likely to report the government still owed them money. These organizations reported that state government was the biggest offender for outstanding payments. This finding should be interpreted with caution, however. Recall that the fiscal conditions of state governments in the complementary group are the weakest of the three groups, so more research is necessary to explore the relationship between late payments and poor fiscal health at the state level.

As previously mentioned, nonprofits in complementary states were more likely to say that reporting requirements were time-consuming. This is, in large part, due to more frequent and more demanding reporting requirements. Nonprofits in the complementary states were more likely to be required to submit a narrative report of program accomplishments and surveys of clients on satisfaction with services received. These reports are more complex and time-consuming than data on individuals served or units of services provided, which were more likely required of nonprofits in the supplemental culture states.

Finally, many nonprofits note challenges when government agencies have different reporting requirements from nonprofits. Once again, we see nonprofits in complementary state cultures were more likely to report their definitions did not align with government agencies in terms of services, budget categories, reporting formats, allowances for administrative or overhead expenses, and outcome reporting requirements compared to their counterparts operating in the supplemental culture group. More research should examine why nonprofits in the independent culture states are more likely to have similar reporting requirements compared to those in complementary culture states, which may be a function of the contract types used in these state cultures.

The last area analyzed in the government-nonprofit relationship centered on feedback nonprofits provided to government about funding issues and/or procedures. Here, we find no significant differences in feedback provided by nonprofits in different state nonprofit cultures. Nonprofits in the complementary environment provided feedback through indirect advocacy (e. g. affiliated organizations or coalitions). Additionally, these nonprofits were also more likely to contact contracts or grants ombudsmen. Further research should explore whether these organizations provided feedback and contacted ombudsmen because these organizations had more problems, and thus, saw feedback as avenue for resolving the issue or if it indicates the organizations felt they could provide feedback without endangering their government funding.

\section{Conclusion}

This paper expands research on the government-nonprofit relationship by testing three distinct nonprofit cultures among the 50 states. There are significant differences in government-nonprofit funding relationships in the complementary, supplementary and independent state cultures, which means nonprofits operating in certain state nonprofit cultures face different types and degrees of risk to their organization's overall health. The strength of the nonprofit infrastructure also varies somewhat among the different state cultures. Future research will allow us to probe the implications of these and other aspects of diverse state cultures and will enrich our understanding of the interactions of nonprofits and state governments.

\section{Notes}

1 Indicators for social structures measure the difference in "socioeconomic development, population size, urbanization, education, occupational status, family structure, social mobility, age distribution, racial diversity, and income inequality" (Lieske 2010, 541).

2 To control for political ideology, Pettijohn and Boris (2017) considered the percent of individuals in the state who voted for President Trump and the number of statewide elected officials that are members of the Republican Party.

3 This variable includes data registration, notice, and filing requirements for charities and fundraisers, location of state regulatory and enforcement powers, and deductibility of charitable contributions on state income taxes (see Lott et al. 2016 for more information).

4 This includes fiscal solvency, revenue sources, and welfare and social service spending.

5 This includes number of nonprofits, revenue, and assets per capita and individual giving to nonprofits.

6 The types and sizes of organizations that participated in the study were similar to the organizations that did not participate. Hence, the potential of nonresponse bias for this study is rather small.

\section{References}

Boris, E. T., E. de Leon, K. L. Roeger, and M. Nikolova. 2010. “Human Service Nonprofits and Covernment Collaboration: Findings from the 2010 National Survey of Nonprofit Covernment Contracting and Grants." Last modified October 7, 2010. 
https://www.urban.org/research/publication/human-service-nonprofits-and-government-collaboration-findings-2010-national-surveynonprofit-government-contracting-and-grants.

Chaves, M., L. Stephens, and ]. Calaskiewicz. 2004. “Does Covernment Funding Suppress Nonprofits' Political Activity?” American Sociological Review 69 (2): 292-316.

Ebaugh, H. R., J. S. Chaftez, and P. F. Pipes. 2005. “Faith-Based Social Service Organizations and Government Funding: Data from a National Survey." Social Science Quarterly 86 (2): 273-92.

Frumkin, P., and M. T. Kim. 2002. “The Effect of Covernment Funding on Nonprofit Administrative Efficiency: An Empirical Test." Accessed February 11, 2018. https://www.innovations.harvard.edu/sites/default/files/2600.pdf.

Grojnberg, K. A. 1993. Understanding Nonprofit Funding: Managing Revenues in Social Services and Community Development Organizations. San Francisco, CA: Jossey Bass.

Gujarati, D. M., and D. C. Porter. 2009. Basic Econometrics, 5th ed. New York, NY: McGraw-Hill Irwin.

Guo, C. 2007. "When Government Becomes the Principal Philanthropist: The Effect of Public Funding on Patterns of Nonprofit Covernance." Public Administration Review 67 (3): 456-71.

Lieske, J. 2010. "The Changing Regional Subcultures of the American States and the Utility of a New Cultural Measure." Political Research Quarterly 63 (3): 538-52. https://doi.org/10.1177/1065912909331425.

Lieske, J. 2012. "American State Cultures: Testing a New Measure and Theory." Publius: the Journal of Federalism 42 (1): 108-33. https://doi.org/10.2307/41441074.

Lott, C., and M. Fremont-Smith. 2017. "State Regulatory and Legal Framework." In Nonprofits and Covernment: Collaboration and Conflict, 3rd ed., edited by E. T. Boris and C. E. Steuerle, 163-90. Lanham, MD: Rowman and Littlefield.

Lott, C. M., E. T. Boris, K. K. Coldman, B. J. Johns, M. Gaddy, and M. R. Farrell. 2016. “State Regulation and Enforcement in the Charitable Sector." Last modified September 13, 2016. https://www.urban.org/research/publication/state-regulation-and-enforcement-charitablesector.

Mayer, L. H. 2016. “The Better Part of Valour Is Discretion: Should the IRS Change or Surrender Its Oversight of Tax-Exempt Organizations?” Columbia Journal of Tax Law 7 (1): 80-122.

McKeever, B. S., N. E. Dietz, and S. D. Fyffe. 2016. The Nonprofit Almanac: The Essential Facts and Figures for Managers, Researchers, and Volunteers. Lanham, MD: Rowman and Littlefield.

Mosley, J. E. 2012. "Keeping the Lights On: How Government Funding Concerns Drive the Advocacy Agendas of Nonprofit Homeless Service Providers." Journal of Public Administration Research and Theory 22 (4): 841-66.

Neumayr, M., U. Schneider, and M. Meyer. 2015. "Public Funding and Its Impact on Nonprofit Advocacy." Nonprofit and Voluntary Sector Quarterly 44 (2): 297-318. https://doi.org/10.1177/0899764013513350.

Nowland-Foreman, G. 2002. "Purchase-of-Service Contracting, Voluntary Organizations, and Civil Society." American Behavioral Science 41 (1): $108-23$.

Peterson, P. E. 1970. “Forms of Representation: Participation of the Poor in the Community Action Program.” American Political Science Review 64 (2): 491-507.

Pettijohn, S. L., and E. T. Boris. (with C. DeVita and S. Fyffe). 2013. “Nonprofits and Government Funding: Findings from the 2013 National Survey of Nonprofit Covernment Contracting and Crants." Last modified December 5, 2013. https://www.urban.org/research/publication/nonprofit-government-contracts-and-grants-findings-2013-national-survey.

Pettijohn, S. L., and E. T. Boris. 2017. State Nonprofit Culture: Assessing the Impact of State Regulation on the Government-Nonprofit Relationship. Grand Rapids, MI: ARNOVA Presentation.

Piven, F. F., and R. A. Cloward. 1971. Regulating the Poor: The Functions of Public Welfare. New York, NY: Patheon.

Rangan, V. K. 2004. “Lofty Missions, Down-To-Earth Plans.” Harvard Business Review 82 (3): 112-19.

Salamon, L. M. 1987. "Partners in Public Service: The Scope and Theory of Covernment-Nonprofit Relations." In The Non-Profit Sector: A Research Handbook, edited by W. W. Powell, 99-117. New Haven, CT: Yale University.

Salamon, L. M. 1995. Partnerships in Public Service. Baltimore, MD: Johns Hopkins University Press.

Smith, S. R., and M. Lipsky. 1993. Nonprofits for Hire: The Welfare State in the Age of Contracting. Cambridge, MA: Harvard University Press.

U. S. Government Accountability Office (GAO). 2009. Extent of Federal Spending under Cost-Reimbursement Contracts Unclear and Key Controls Not Always Used. Report No. CAO-09-921.Washington, DC. https://www.gao.gov/products/CAO-09-921.

U.S. Government Accountability Office (CAO). 2010. Treatment and Reimbursement of Indirect Costs Vary among Crants, and Depend Significantly on Federal, State, and Local Covernment Practices. Report No. GAO-10-477. Washington, DC. https://www.gao.gov/new.items/d10477.pdf.

Van Til, J. 1988. Mapping the Third Sector: Voluntarism in a Changing Social Economy. New York, NY: The Foundation Center.

Verschuere, B., and ]. De Corte. 2014. “The Impact of Public Resource Dependence on the Autonomy of NPOs in Their Strategic Decision Making." Nonprofit and Voluntary Sector Quarterly 43 (2): 293-313. https://doi.org/10.1177/0899764012462072.

Wildavsky, A. 1987. “Choosing Preferences by Constructing Institutions." American Political Science Review 81 (1): 3-21. https://doi.org/10.2307/1960776.

Young, D. R. 1999. “Complementary, Supplementary or Adversarial: A Theoretical and Historical Examination of Covernment-Nonprofit Relations in the U.S." In Covernment and Nonprofit Organizations: The Challenges of Civil Society, edited by E. T. Boris and C. E. Steurele, 3167. Washington, DC: The Urban Institute.

Young, D. R. 2000. "Alternative Models of Government-Nonprofit Sector Relations: Theoretical and International Perspectives." Nonprofit and Voluntary Sector Quarterly 29 (1): 149-72. https://doi.org/10.1177/0899764000291009. 